\title{
A Contribution to Byzantine Prosopography: Constantine Chage
}

Abstract: The paper discusses the career of Constantine Chage, a prominent Byzantine military official from the $11^{\text {th }}$ century, as attested in literary and sigillographic sources. It contributes to the debate over the dating of the events in which Chage was involved, and comments on the possible origin of his family name. Presenting two of the seals issued by the official, the author suggests a possible reading of the inscriptions.

Key words: Byzantium, prosopography, sigillography, administration, Constantine Chage

UDK: 94:929Hage

\section{Prispevek k bizantinski prozopografiji: Konstantin Hage}

Izvleček: Avtor članka razčleni kariero Konstantina Hageja, uglednega bizantinskega vojaškega uradnika iz 11. stoletja, kakor se izriše v književnih in sigilografskih virih. Pridruži se razpravi o dataciji dogodkov, v katere je bil vpleten Hage, in komentira možni izvor

\footnotetext{
${ }^{1}$ Dr. Pantelis Charalampakis is a post-doctoral researcher (supported by the State Scholarship Foundation - IKY) at the Research Centre for Byzantine and Post-Byzantine Art, Academy of Athens. E-mail: pantelcha@gmail.com. ${ }^{2}$ Special acknowledgements are due to Prof. Kay Ehling, director of the Staatliche Münzsammlung München, and to Dr. Emanuel Viorel Petac, curator at the Romanian Academy, for granting permission to publish or re-publish the images of Constantine's seals (the abovementioned institutions reserve the rights on these images). Likewise to Prof. J.-Cl. Cheynet, who kindly offered information about the BnF specimen.
} 
njegovega priimka. Reproducira tudi dva pečata, ki ju je izdal Hage, in predlaga, kako bi bilo mogoče prebrati napisa.

Key words: Bizanc, prozopografija, sigilografija, uprava, Konstantin Hage

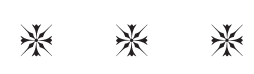

Over the last years, researchers have increasingly focused on Byzantine prosopography and administration, these two topics being crucial for the understanding of Byzantine history in general and social history in particular. Three major prosopographical dictionaries have been published recently, aiming to cover - together with the older Prosopography of the Later Roman Empire (mid- $3^{\text {rd }}$ to late $7^{\text {th }}$ centuries) - all periods of Byzantine history: the Prosopographie der mittelbyzantinischen Zeit (641-1025), the online Prosopography of the Byzantine World (officially it covers the period of $1025^{-1150}$, but in fact from the very late $10^{\text {th }}$ to the mid$13^{\text {th }}$ centuries), and the Prosopographisches Lexikon der Palaiologenzeit (1261-1453). However, it has become clear to scholars working on prosopography and administration that the traditional study of literary texts is no longer sufficient. None of these topics can be properly investigated separately from sigillography - that is, the study of Byzantine seals made of gold, silver or, as in most cases, lead. Sigillography is very important to prosopographical studies, as each seal provides information about its owner that would otherwise remain unknown to us. It is thus inevitable that, together with prosopography, sigillography should attract scholarly attention.

Below we will attempt to present the career of Constantine (Konstantinos) Chage, an $11^{\text {th }}$ century Byzantine official, whose service 
is documented not only through literary sources, but also through the seals issued by Chage himself.

Constantine Chage is clearly mentioned in only two instances by two Byzantine chroniclers: Skylitzes and Kedrenos (who actually copied from Skylitzes). First, we learn that in the year 1035, when in charge of the thematic Byzantine fleet of the Kibyrraiotai (a maritime theme in south-eastern Asia Minor), he defeated the Arabs raiding the Asia Minor coasts and captured five hundred of them, whom he sent as prisoners to Constantinople. ${ }^{3}$ The second occurrence in the sources tells the following story: On April 20, 1042, Michael V died and the throne of Constantinople was taken over by two sisters, Zoe and Theodora. As soon as the news reached Theophilos Erotikos, the Byzantine general (strategos) of Cyprus, he rebelled against the Empresses. Erotikos was supported by the population of Cyprus (who had suffered from the high taxation imposed by state officials) and part of the island's military forces. It seems that the palace was unable to react, but on June 11 of the same year, Constantine IX married Zoe and immediately decided to crush the rebellion. For this purpose he called the patrikios (a high-ranking title) Constantine Chage, strategos (general) of the Kibyrraiotai. Chage managed to defeat the rebels and to capture Erotikos, whom he sent to the Emperor. ${ }^{4}$

The dating of the abovementioned events requires some commentary. The first episode (the battle with the Arabs) has been placed in 1034 (Svoronos), 1035 (Lounghis; Savvides; Svoronos; Wassiliou), 1036 (Lounghis; Savvides), and even in 1037 (Lounghis; Savvides). ${ }^{5}$ Based

\footnotetext{
${ }^{3}$ Skylitzes, 1973, 398-399; Kedrenos, 1839, 514.

${ }^{4}$ Skylitzes, 1973, 429; Kedrenos, 1839, 549-550; Zonaras, 1897, 624; Glykas,1836, 594-595. The latter two authors do not mention Chage's involvement in the episode of Cyprus.

${ }^{5}$ Svoronos, 1959, 73, note 1; Savvides, 1996, 36; Savvides, 1998, no. 63; Wassiliou, 2004, 409; Lounghis, 2010, 68, notes 508, 163.
} 
on the succession of the events, the correct date seems to be the summer of 1035. Regarding the second case and the end of Chage's service in the theme of the Kibyrraiotai, we agree with Le Beau and Cheynet that the incident on Cyprus took place not in 1043 (see below) but in the late spring or midsummer of $1042,{ }^{6}$ immediately after the ascension of the two Empresses to the throne of Constantinople. This is confirmed by the sources which clearly state that Erotikos rebelled when he learned of the Emperor's death. One can hardly assume that he would have waited for a whole year before acting against the central government. Moreover, we know that in mid-1043, another person, Constantine Kaballourios, served as general in the Kibyrraiotai theme (and was eventually killed by the Rus' while defending Constantinople). ${ }^{7}$ By contrast, several scholars date the Cyprus incident to 1041 (Svoronos) or 1043 (Guilland, early; Gregory; Lounghis; Wassiliou). Savvides chose not to participate in the discussion, by placing the event in 1042-1043 and quoting all scholarly opinions up to that day (in one of his previous studies, however, he had accepted early 1043). ${ }^{8}$ It should be noted that Savvides was wrong to write that I. Thurn (the editor of Skylitzes' chronicle) accepted the year 1043. Actually, Thurn noted down the year 1043 for the next paragraph in the text, where another episode is mentioned. Thus it is very likely that Chage was promoted (see below) after his victory on Cyprus, but this could not have happened immediately after the Cyprus events. It is therefore difficult to accept that Chage left the Kibyrraiotai in June or July 1043. This must have certainly occurred after mid-1042 but also before mid-1043.

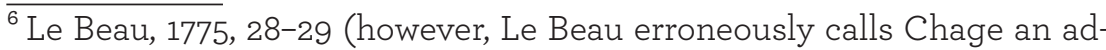
miral of the imperial fleet, while he was actually the general of a thematic, i.e. provincial fleet); Cheynet, 1990, 56, no. 59.

7 Skylitzes, 1973, 432-433; Kedrenos, 1839, 554.

${ }^{8}$ Svoronos, 1959, 73, note 1; Guilland, 1971, 5; Gregory, 1991, 567; Wassiliou, 2004, 409; Lounghis, 2010, 51, 135, 163; Savvides, 1996, 35-36.
} 
Chage's career in the theme of the Kibyrraiotai is known to us not only from the abovementioned literary sources, but also through sigillographic evidence. One of his lead seals survives and is kept today at the Bibliothèque nationale de France in Paris (BnF Zacos 90). This unpublished specimen ${ }^{9}$ previously belonged to the private collection of George Zacos (1911-1983) and was donated after its owner's death to the BnF by his widow, Janet Zacos. According to the inscription, Constantine Chage was patrikios and strategos of the Kibyrraiotai.

Thanks to the combined evidence from sigillographic and literary sources, we know who preceded and who succeeded Chage as general of the Kibyrraiotai. George, a protospatharios (a middle-tohigh ranking title in State hierarchy at that time), whose seal is dated within the first third of the $11^{\text {th }}$ century, was most likely serving in the Kibyrraiotai theme before Chage. ${ }^{10}$ In 1043 Chage was succeeded by Constantine Kaballourios, but the latter was killed in battle soon afterwards. ${ }^{11}$

It seems that the story of Constantine Chage does not end here. As we have already mentioned, he crushed the rebels on Cyprus in the summer of 1042, but in the following summer (of 1043) another person was appointed to serve as general of the Kibyrraiotai. What happened to Constantine Chage? It is almost certain that after his victorious mission on Cyprus he was promoted to general of the

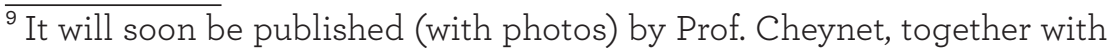
other as yet unknown specimens from the $\mathrm{BnF}-\mathrm{Zacos}$ collection.

${ }^{10}$ This specimen appeared in the auction market: Münz Zentrum 75 (1416 April 1993), no. 1591 (= repetition of Müller (Solingen) 72 (23 Oct. 1992), no. 696 = repetition of Künker 21 (16-18 March 1992), no. 1161). See also SBS 1999, 144, 149; SBS, 1993, 191.

${ }^{11}$ Skylitzes, 1973, 432-433; Kedrenos, 1839, 554. See also: Lounghis, 2010, 62, 164; Wassiliou, 2004, 409; Savvides, 1998, no. 64; Gfrörer, 1877, 281-282.
} 


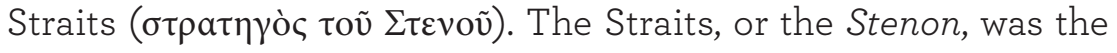
Thracian Bosporus, that is, the waters around Constantinople. ${ }^{12}$ This is evidenced by an unpublished lead seal kept at the State Numismatic Collection in Munich (Staatliche Münzsammlung München 750: diameter (total): 28x25 mm; diameter (field): 23 mm; weight: $13.45 \mathrm{~g}$; struck off centre).
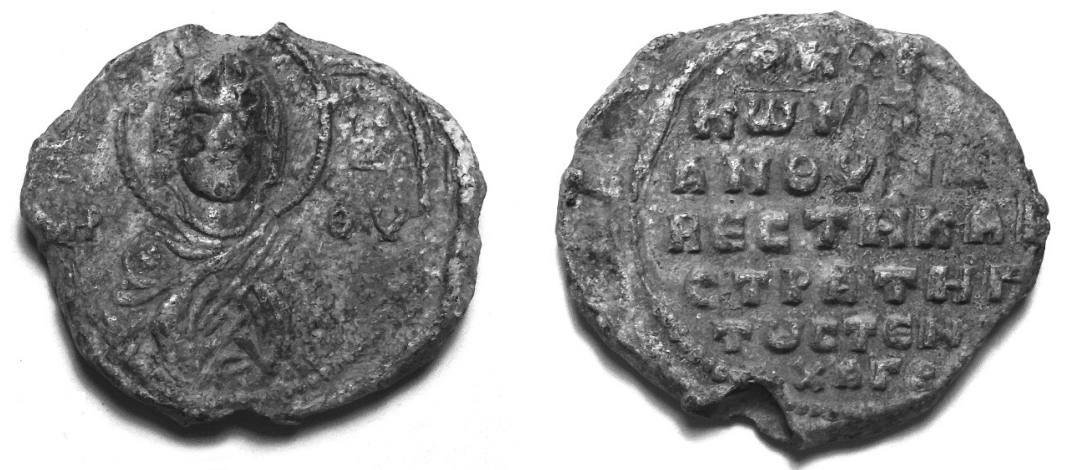

(c) SMM (photo P. Charalampakis)

Obverse: image of Theotokos in 'Minimalorantengestus'; sigla; border of dots:

$M \bar{P}-\theta \bar{V}$

$\operatorname{M\eta ́}(\tau \eta) \rho-\Theta(\varepsilon 0) \tilde{v}$

Reverse: inscription in seven lines; border of dots:

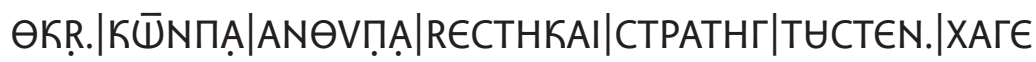
$\Theta(\varepsilon \circ \tau \dot{)}) \kappa(\varepsilon) \beta($ oń) $[\theta(\varepsilon \iota)] / K \omega v(\sigma \tau \alpha v \tau i v \omega) \pi \alpha(\tau \rho ı k i \omega) / \dot{\alpha} v \theta v \pi \dot{\alpha}(\tau \omega)$ or

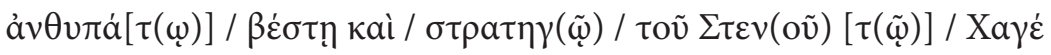

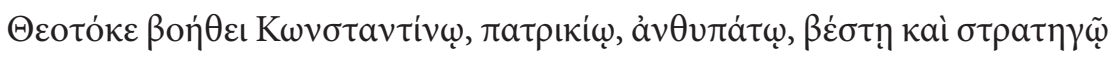

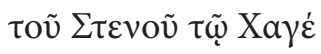

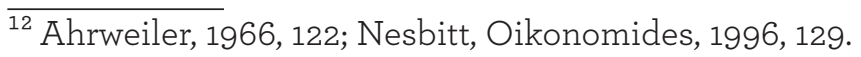


Mother of God, aid Constantine Chage, patrikios, anthypatos, vestes and strategos of the Straits.

It is obvious from his honorific titles that Constantine was a high-ranking official around the mid- $11^{\text {th }} \mathrm{c}$. When exactly he was appointed as strategos (general) of the Stenon is impossible to say. Unless we are missing a stage in his career, he must have been appointed as strategos of the Stenon immediately after his service with the Kibyrraiotai. At some point during his service at the Stenon he was promoted to the even higher title of vestarches, as attested by a lead seal today kept at the Orghidan collection of the Romanian Academy of Sciences in Bucharest (Orghidan 234: diameter (total): $25 \mathrm{~mm}$; diameter (field): $23 \mathrm{~mm}$; struck off centre; corroded). ${ }^{13}$ This specimen was part of the private collection of Constantin Orghidan (1874-1944), who generously donated it in his will to the Romanian Academy.
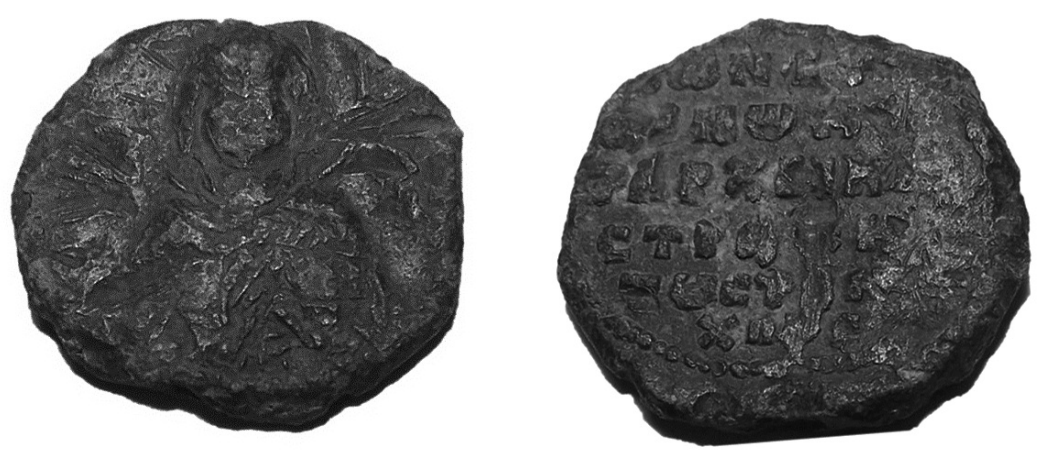

(C) Romanian Academy (photo E. V. Petac)

Obverse: image of Theotokos (indeterminate type, but probably the so-called 'Minimalorantengestus').

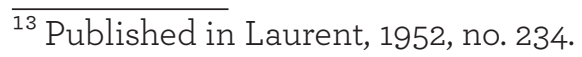


Reverse: inscription in six lines; border of dots:

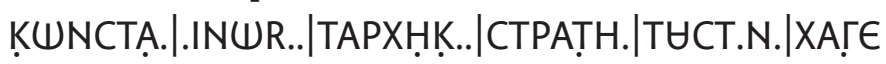

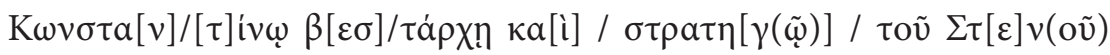
$[\tau(\tilde{\omega})] / \mathrm{Xa \gamma} \dot{\varepsilon}$.

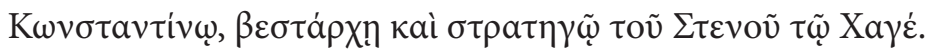

[Mother of God, aid] Constantine Chage, vestarches and strategos of the Straits.

The first editor of the seal, V. Laurent, suggested a different reading: $K \omega v \sigma \tau(\alpha \nu) /[\tau] i v \omega \beta[\varepsilon \sigma] / \tau \dot{\alpha} \rho \chi \eta \kappa \alpha[i] / \sigma \tau \rho \alpha[\tau] \eta[\gamma \tilde{\omega}] / \tau o \tilde{v} \Sigma \tau[\varepsilon] v[o \tilde{u}]$

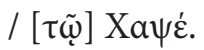

Laurent did not recognise the family name Chage but read Chapse (Xa $\psi \dot{\varepsilon}$ ) instead, a name which he took to be of Georgian origin. A closer examination of the inscription reveals the letters to form the name ХАГE, although $\Gamma$ is half-destroyed and not entirely visible. Moreover, at that time (mid-11 $1^{\text {th }}$ century) the title of vestarches was superior to that of patrikios, and this supports the idea of promotion.

Provided that the identification of the person is more than certain, as W. Seibt has also suggested, ${ }^{14}$ we may attribute to the same individual the two seals struck from the same boulloterion and kept today in the Dumbarton Oaks collection: they mention 'Constantine (without family name), vestarches, krites of the Velon, and strategos of the Stenon'.

a. DO 47.2.255 (diameter (total): $22 \mathrm{~mm}$; weight: $7.4 \mathrm{~g}$; blank is smaller than die; chipped; corroded). ${ }^{15}$

\footnotetext{
${ }^{14}$ See W. Seibt's reviews on Jordanov, Preslav (1993), in: Byzantinische Zeitschrift 89 (1996), 137, and Laurent, Orghidan (1952), in: Jahrbuch der Österreichischen Byzantinistik 53 (2003), 199.

${ }^{15}$ Published in Nesbitt, Oikonomides, 1996, no. 73.1(a).
} 
Obverse: inscription in five lines (four surviving): [+ K(v่ $\rho) \varepsilon$ $\beta(o \eta ́) \theta(\varepsilon ı)] /[\tau] \tilde{\omega} \sigma \tilde{\omega} \delta[o u ́(\lambda \omega)] /[K] \omega v(\sigma \tau \alpha v \tau i v \omega) \beta \varepsilon \sigma /[\tau] \dot{\alpha} \rho x(\eta) \kappa[\rho(\iota)] / \tau(\tilde{\eta})$

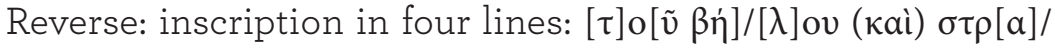
$[\tau] \eta \gamma \tilde{\omega} \tau[o \tilde{u}] /[\Sigma] \tau \varepsilon v o \tilde{v}$.

b. DO 58.106.3014 (diameter (total): $32 \mathrm{~mm}$; weight: $26.68 \mathrm{~g}$; corroded). ${ }^{16}$

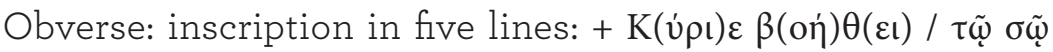

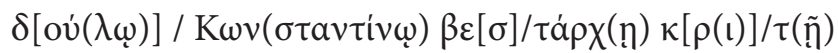

Reverse: inscription in four lines with decoration; border of dots:

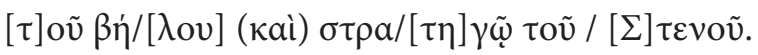

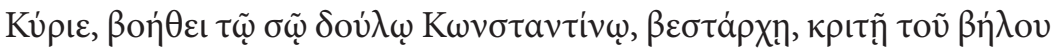

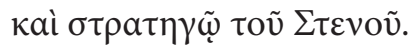

Lord, aid your servant Constantine, vestarches, judge of the Velon and general of the Straits.

These two seals mention Constantine's judicial office as the judge of the Velon (a civil office) together with a military office that of general; this unusual combination can be explained, according to Nesbitt and Oikonomides, by the fact that 'the strategos of the Stenon had also the exclusive right to judge all affairs of the Jews of Constantinople up until the very late XIIth century. But other trials were also held at the Stenon. This explains why the owner of the following seal, although a strategos, was also a judge attached to the supreme tribunal of Constantinople. ${ }^{17}$ To this we may add that the title of vestarches was often (but certainly not exclusively) awarded to judicial officials. A Byzantine legal document provides further evidence on the judicial tasks of the strategos of

\footnotetext{
${ }^{16}$ Published in Nesbitt, Oikonomides, 1996, no. 73.1(b).

${ }^{17}$ Nesbitt, Oikonomides, 1996, 129.
} 


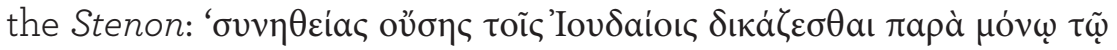

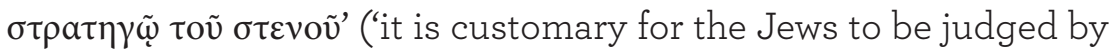
the general of the Straits exclusively'). ${ }^{18}$ In this context it is very likely that Chage exercised judicial tasks from the very beginning of his appointment as strategos of the Stenon, but he chose not to mention this on the seal from the Orghidan collection (that would have been difficult in any case, since the obverse was already occupied by a Holy Person and there was not much space left on the reverse; by contrast, the other two specimens that may be attributed to him bear inscriptions on both sides). It is difficult to say, though, which boulloterion (the one of the Orghidan specimen or the one of the DO specimens) was earlier.

The early $12^{\text {th }}$ century Latin chronicle known as Chronicon Anonymi Barensis contains a reference to a person called Chagea ( ${ }^{*}$ Xaýa ?), sent in the autumn of 1045 to Southern Italy in order to accompany there the newly appointed katepano (governor) and then return to the capital with the retired one: 'Mill. XLV. Ind. XIII. Et venit Chagea, \& Catapanus Palatino in Bari. Et Argiro ibit cum Chagea Constantinopolim cum suis, \& ipse Catapanus remansit Bari. ${ }^{19}$ This Chagea must have been a confidant to the Emperor, and our Constantine Chage, a very experienced and skilled official promoted to service in the capital, could well be the one who undertook this important mission. Unfortunately, no other chronicle related to this text (the Annales Barenses and the chronicle of Lupus Protospatharius) includes this piece of information.

For a better grasp of this short study on Constantine Chage, family names should be considered as well. It is true that Laurent

\footnotetext{
${ }^{18}$ Rhalles, Potles, 1852, 41. Cf. Peira, in Zepos, Zepos, 1931, 214 (51.10). ${ }^{19}$ Chronicon Barensis, 150-151. On the events accompanying the change of the katepano, see also Cheynet, 2007, 155-157; Von Falkenhausen, 1978, 98.
} 
should have read XАГE instead of XАYE, as Seibt pointed out, but the family name Chapsas (and not Chapse, as Laurent read) really did exist. It is documented on seals issued from a single boulloterion and found in the area of Preslav, Bulgaria. All four specimens were published by I. Jordanov ${ }^{20}$ and there is no doubt about the

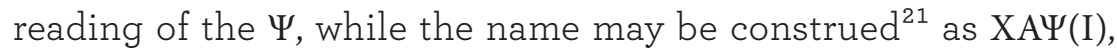
$\mathrm{XA \Psi}(\mathrm{E})$, and $\mathrm{XA \Psi}(\mathrm{A})$, the last form being, in our view, the best option. Indeed, the family name Chapsas is registered in the PLP (nos. 30739-30748) and documented from the second half of the $13^{\text {th }}$ century to the $15^{\text {th }}$ century in Trabzon (Trebizond). Interestingly, Trebizond yields a couple of similar names as well (Chapsaba, Chapsonomitas) (PLP, nos. 30738 and 30749 respectively).

Most likely, the name Chage (attested as Xax' / Chache in one of Skylitzes' manuscripts) is not of Greek origin, but no explanation has been suggested so far. It may be of Arabic, Persian, or other Asiatic origin. This is - perhaps - reinforced by the case of Chase (a misspelled form of Chage?) in the mid- $10^{\text {th }}$ c., a protospatharios of Saracen (i.e. Arabic) origin documented by Constantine VII Porphyrogennetos, the Continuator of Theophanes, and other literary sources. ${ }^{22}$ Moreover, it remains unclear whether there is any relation

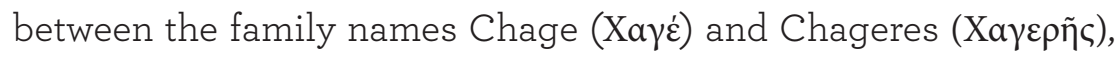
the latter registered in the Athonite documents of the $14^{\text {th }} \mathrm{c}$., but we believe that these two names are of different origins.

In fact, apart from the case of our Constantine, there is little evidence of this mysterious family name. The earliest reference comes from the

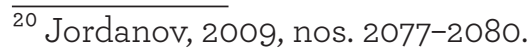

${ }^{21}$ As W. Seibt suggested in his review of Jordanov, Corpus 2 (2006), in: Byzantinische Zeitschrift 101 (2008), 823, the $\Psi$ is not followed by an I (iota) but by an abbreviation mark.

${ }^{22}$ Porphyrogennetos, 242 (chapter 50); Theophanes Continuatus, 388. See also PmbZ, no. 21238 and the comments in Jenkins, 1962, 193.
} 
mid- $11^{\text {th }}$ century register of the area of Thebes in central Greece: ' $\Delta i \grave{a}$

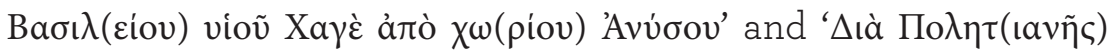

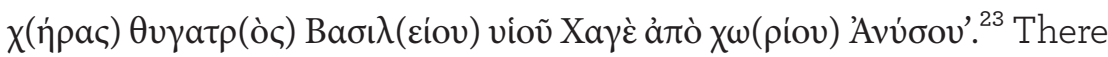
is no indication in the text that this Basil (Basileios) Chage was a prominent landlord. The next reference comes from very far away: late medieval Cyprus. Nine individuals bearing the family name Chage are registered in an obituary published by Darrouzès more than half a century ago. The earliest is a certain Basileios Chage, a landowner who passed away on June 1, 1348. He originated from, or resided in, the village of Loimon on Western Cyprus, close to Paphos. He bequeathed to the Monastery of the Priests ( $\mu$ ovì $\tau \tilde{\omega} v$ 'I $\varepsilon \varepsilon \varepsilon \omega v$ ) a nearby vineyard as well as some domestic animals. ${ }^{24}$ The next persons on the list by chronological order are the nun Theodoule and her father, whose first name was not registered. According to the document, Theodoule passed away on July 16, 1382, while residing at the monastery of Saint Georgios Koudounas. ${ }^{25}$ Despite our efforts, it was not possible to locate and/or identify any monastery with this name on Cyprus. It is very likely, though, that Chage, her father, remained on Cyprus while she resided at the monastery of Saint Georgios Koudounas, situated on the island of Prinkipos (Prince's Island, modern-day Büyükada), the only monastery of this name. Only a few years later, on December 31, 1387, a certain monk Gerasimos, son of Chage, passed away. As was the case with Basileios, his place of origin was the village of Loimon on Western Cyprus. ${ }^{26}$ Another Basileios Chage, together with his wife Elene, donated on May 3, 1397, an ox to the Monastery of the Priests. ${ }^{27}$ The latest reference to

\footnotetext{
${ }^{23}$ Svoronos, 1959, 14, 17-18.

${ }^{24}$ Darrouzès, 1951, 48, f. 232; PLP, no. 30341.

${ }^{25}$ Darrouzès, 1951, 53, f. 261; PLP, no. 30339.

${ }^{26}$ Darrouzès, 1951, 34, f. 107; PLP, no. 30342.

${ }^{27}$ Darrouzès, 1951, 43, f. 208; PLP, no. 30340.
} 
the Chage family dates from 1407, when (on March 29) the monk Theodoretos, son of a certain Chage, passed away. ${ }^{28}$ There is no clear indication of his place of origin, but a reference to the village of Loimon in the preceding passage might be strong evidence. Besides, more members bearing the name of Chage are linked to this village.

There is no doubt that the abovementioned manuscript provides valuable information about the Chage family. But some questions still remain unanswered: what was the connection between the family from Western Cyprus and the individual from Thebes? Was Constantine Chage related to the Theban or to the Cypriot branch? What was the origin of the name Chage and of the family itself? For the time being there is no answer to these issues. Yet the Paris manuscript might be useful again: a certain Tzerar Chantze (followed by another name, perhaps a nickname, which is now missing) was married in the monastery of Saint Eutychios on Cyprus in the mid- $14^{\text {th }} c{ }^{29}$ His first name is of Western European origin (Gerard?), ${ }^{30}$ while his family name resembles that of Chage. It is important to note here that a similar name, Chantzales (see PLP, no. 30587, early $15^{\text {th }}$ c.), was very likely of Turkish origin. Would this mean that Chage is a Hellenised form of Chantze? Moreover, is there any relation between the names Chage and Chantze and the Turkish words 'hoca' or 'hacl'? If so, then we should look for either Turkish or Arabic origins. Even more useful is the information provided by Ibn Bibi. According to his work, one Pervane, of Iranian origin, was vizier in the court of the Seljuks of Rum in Asia Minor in the mid$13^{\text {th }} \mathrm{c}$. This Pervane was somehow allied to 'the son of Hāğă', the latter name pronounced as Xaya and definitely related to the name

\footnotetext{
${ }^{28}$ Darrouzès, 1951, 40, f. 186; PLP, no. 30343.

${ }^{29}$ Darrouzès, 1951, 48, f. 234; PLP, no. 30590.

${ }^{30}$ Perhaps a remnant of the Lusignan era of Cyprus?
} 
Chage (Xare). This person is clearly stated in the text to have been of Turkish ancestry. ${ }^{31}$

The absence of information about the Chage family from Byzantine literature and other sources (seals, inscriptions) suggests that the family may not have been among the key players in either military or civil aristocracy of $11^{\text {th }}$ century Byzantium and/or later, although this assumption might be changed by new evidence. Apparently Constantine Chage was a skilful person who successfully fulfilled his duties in every position he held and thus ascended the hierarchy as a self-made man. Hopefully, more seals issued by this remarkable personage or other members of the family will be discovered, to shed more light upon his impressive career and his family.

\section{Bibliography}

AHRWEILER, H. (1966): Byzance et la Mer, Paris.

CHEYNET, J.-CL. (1990): Pouvoir et contestations à Byzance (9631210), Paris.

CHEYNET, J.-CL. (2007): La place des catépans d'Italie dans la hié-

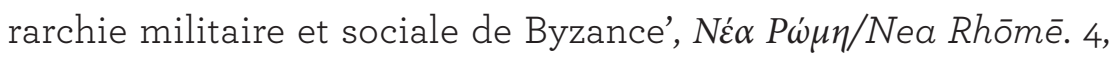
143-161.

CHRONICON BARENSIS: Muratori, L. A. (ed. 1724), Chronicon ignoti civis Barensis sive Lupis Protospatae, cum notis Camilli Peregrini, in: Rerum Italicarum Scriptores. Vol. 5, Milan.

DARROUZĖS, J. (1951): "Un obituaire chypriote: le Parisinus Grae-

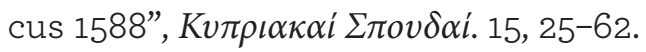

JENKINS, R. (ed. 1962): Constantine Porphyrogenitus, De Administrando Imperio. Vol. 2 (Commentary), London.

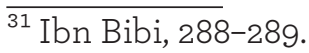


GFRÖRER, A. FR. (1877): Byzantinische Geschichten. Vol. 3, Graz. GLYKAS: Bekker, I. (ed. 1836), Michaelis Glycae Annales, Bonn. GREGORY, T. E. (1991): "Cyprus”, in: The Oxford Dictionary of Byzantium. Vol. 1, New York, Oxford.

GUILLAND, R. (1971): “Contribution à la prosopographie de l'Empire Byzantin. Les patrices sous le règne de Constantin IX Monomaque (1042-1054)", Zbornik Radova Vizantološkog Instituta. 13, 1-25.

IBN BIBI: Duda, H. W. (transl. 1959), Die Seltshukengeschichte des Ibn Bībī, Kopenhagen.

JORDANOV, I. (2009): Corpus of Byzantine seals from Bulgaria. Vol. 3, Sofia.

KEDRENOS: Bekker, I. (ed. 1839), Georgius Cedrenus. Vol. 2, Bonn. LAURENT, V. (1952): La collection C. Orghidan, Paris.

LE BEAU, CH. (1775): Histoire du Bas-Empire. Vol. 17, Paris.

LOUNGHIS, T. (2010): Byzantium in the Eastern Mediterranean: Safeguarding East Roman Identity (407-1204), Nicosia.

NESBITT, J., OIKONOMIDES, N. (1996): Catalogue of Byzantine seals at Dumbarton Oaks and in the Fogg Museum of Art. Vol. 3, Dumbarton Oaks, Washington D.C.

PLP: Trapp, E., et al. (ed. 1976-1995), Prosopographisches Lexikon der Palaiologenzeit (Vols. 1-14; Appendices 1-2), Vienna.

PMBZ: Winkelmann, F., et al. (ed. 1998-2013), Prosopographie der mittelbyzantinischen Zeit, Abteilung I: 641-867 (Vols. 1-6); Abteilung II: 867-1025 (Vols. 1-8), Berlin, New York.

PORPHYROGENNETOS: Moravcsik, G., Jenkins, R. (ed. 1967), Constantine Porphyrogenitus, De Administrando Imperio, Dumbarton Oaks, Washington D. C.

RHALLES, G., POTLES, M. (1852): $\Sigma v ́ v \tau \alpha \gamma \mu \alpha \tau \omega v \theta \varepsilon i \omega v \kappa \alpha \iota \iota \rho \omega \dot{v} \kappa \alpha-$ vóvwv. Vol. 1, Athens. 


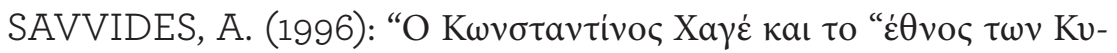

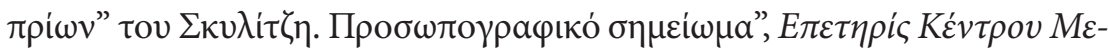

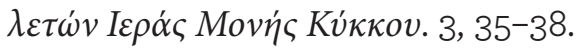

SAVVIDES, A. (1998): "The secular prosopography of the Byzantine maritime theme of the Carabisians/Cibyrraeots", ByzantinoSlavica. 59/1, 24-45.

SBS (1993, 1999): Studies in Byzantine Sigillography. Vols. 3, 6.

SKYLITZES: Thurn, I. (ed. 1973), Ioannis Scylitzae Synopsis Historiarum, Berlin, New York.

SVORONOS, N. (1959): 'Recherches sur le cadastre byzantin et la fiscalité aux XIe et XIle siècles: le cadastre de Thèbes', Bulletin de Correspondance Hellénique. 83, 1-145.

THEOPHANES CONTINUATUS: Bekker, I. (ed. 1838), Chronographia, Bonn.

VON FALKENHAUSEN, V. (1978): La dominazione bizantina nell'Italia meridionale dal IX all'XI secolo, Bari.

WASSILIOU, A.-K. (2004): 'Beamte des Themas der Kibyrraioten', in: Tabula Imperii Byzantini 8 (Lykien und Pamphylien). Vol. 1, Wien, 407-413.

ZEPOS, I., ZEPOS, P. (1931): Jus Graecoromanum. Vol. 4, Athens. ZONARAS: Büttner-Wobst, Th. (ed. 1897), Ioannis Zonarae Epitomae Historiarum, Libri XIII-XVIII, Bonn. 